\title{
Correction to: A new type of singular perturbation approximation for stochastic bilinear systems
}

\section{Martin Redmann ${ }^{1}$}

Published online: 1 July 2021

(C) The Author(s) 2021

\section{Correction to: Mathematics of Control, Signals, and Systems (2020) 32:129-156 https://doi.org/10.1007/s00498-020-00257-9}

The article "A new type of singular perturbation approximation for stochastic bilinear systems", written by Martin Redmann, was originally published online on 25 May 2020 without Open Access. After publication in volume 32, issue 2, pages 129-156, the author decided to opt for Open Choice and to make the article an Open Access publication. Therefore, the copyright of the article has been changed to (C) The Author(s) 2021 and the article is forthwith distributed under the terms of the Creative Commons Attribution 4.0 International License, which permits use, sharing, adaptation, distribution and reproduction in any medium or format, as long as you give appropriate credit to the original author(s) and the source, provide a link to the Creative Commons licence and indicate if changes were made. The images or other third-party material in this article is included in the article's Creative Commons licence, unless indicated otherwise in a credit line to the material. If material is not included in the article's Creative Commons licence and your intended use is not permitted by statutory regulation or exceeds the permitted use, you will need to obtain permission directly from the copyright holder. To view a copy of this licence, visit http://creativecommons.org/ licenses/by/4.0..

Open Access This article is licensed under a Creative Commons Attribution 4.0 International License, which permits use, sharing, adaptation, distribution and reproduction in any medium or format, as long as you give appropriate credit to the original author(s) and the source, provide a link to the Creative Commons licence, and indicate if changes were made. The images or other third party material in this article are included in the article's Creative Commons licence, unless indicated otherwise in a credit line to the material. If

The original article can be found online at https://doi.org/10.1007/s00498-020-00257-9.

$\triangle$ Martin Redmann

martin.redmann@mathematik.uni-halle.de

1 Institute of Mathematics, Martin Luther University Halle-Wittenberg, Theodor-Lieser-Str. 5, 06120 Halle (Saale), Germany 
material is not included in the article's Creative Commons licence and your intended use is not permitted by statutory regulation or exceeds the permitted use, you will need to obtain permission directly from the copyright holder. To view a copy of this licence, visit http://creativecommons.org/licenses/by/4.0/.

Publisher's Note Springer Nature remains neutral with regard to jurisdictional claims in published maps and institutional affiliations. 